\title{
Environmental Disclosure: Determinants and Effects on Financial Performance? An Empirical Evidence from Turkey
}

\author{
Ismail KALASH (https://orcid.org/0000-0002-0674-0136), Department of Business Management, Dicle \\ University, Turkey; e-mail: ismailkalash2@gmail.com
}

\section{Çevresel Açıklama: Belirleyiciler ve Finansal Performans Üzerindeki Etkileri? Türkiye'den Ampirik Bir Kanıt}

\begin{abstract}
This article investigates the determinants of public disclosure of environmental information by firms and its effect on their financial performance. Using a sample of 66 firms listed on Istanbul Stock Exchange during the period of 2014-2018, we find that highly leveraged and larger firms, and firms with higher equity agency costs are more likely to disclose environmental information. However, the results indicated that profitability, industry type, information asymmetry, investment opportunities and business risk do not affect the probability that the firm will disclose environmental information. Finally, we find a weak evidence that environmental disclosure affects the financial performance of Turkish firms.
\end{abstract}

Keywords $\quad$ : Environmental Disclosure, Determinants, Financial Performance.

JEL Classification Codes : $\quad$ Q50, G30.

Öz

$\mathrm{Bu}$ çalışma, çevresel açıklamanın belirleyicileri ve finansal performans üzerindeki etkilerini incelemektedir. Borsa İstanbul'da (BİST) hisse senetleri işlem gören 66 firmanın 2014-2018 yıllarına ait verilerini kullanarak yüksek kaldıraca ve yüksek özkaynağın temsilci (vekalet) maliyetlerine sahip firmalar ve büyük firmaların çevresel bilgiler açıklama olasılığının daha yüksek olduğu tespit edilmiştir. Yine, karlılık, endüstri tipi, bilgi asimetrisi, yatırım fırsatları ve faaliyet riskinin firmanın çevresel bilgiler açıklama ihtimalini etkilemediği ortaya çıkmıştır. Bununla birlikte, çevresel açıklamanın Türk firmaların finansal performansını etkilediği ile ilgili zayıf bir kanıt bulunmuştur.

Anahtar Sözcükler $\quad$ : Çevresel Açıklama, Belirleyiciler, Finansal Performans. 
Kalash, I. (2020), "Environmental Disclosure: Determinants and Effects on Financial

Performance? An Empirical Evidence from Turkey", Sosyoekonomi, Vol. 28(46), 95-115.

\section{Introduction}

Companies and industrial activities bear primary responsibility for environmental problems (climate change, global warming ......) and their disastrous consequences e.g. natural disasters, famine, water shortage, wars and millions of refugees. According to the "CDP Carbon Majors Report 2017", just 25 firms are responsible for 51\% of global industrial greenhouse gas emissions; 100 companies account for $71 \%$ of these emissions since $1988^{1}$. Corporate environmental performance becomes more important issue for stakeholders because of the harmful impact of firm's operations on environment. Society and government are pressuring firms to disclose more environmental information $(\mathrm{Lu} \&$ Abeysekera, 2014: 428), and to adopt a production strategy that improves the environmental performance, provides low-carbon products and reduces greenhouse gas emissions and environmental pollution. In response to these pressures, environmental issues are increasingly considered in firms' activities. Moreover, firms disclose more information about their operations and activities to enhance their reputation (Gray et al., 2001: 330), and to decrease information asymmetry (Clarkson et al., 2008: 314), agency costs and the cost of capital (Gray et al., 2001: 329; Rover et al., 2015: 6). All these benefits encourage managers to be forthcoming, and to present good environmental behaviour.

The motives of environmental disclosure have been discussed according to many theories: legitimacy theory, stakeholder theory, and information cost theory (Michelon \& Parbonetti, 2012: 5; Dejean, 2009: 61). According to the legitimacy theory, firms disclose environmental information to legitimize their activities and operations within society. In this context, firms attempt to satisfy the requirements and expectations of society (Deegan, 2002: 293; Dejean, 2009: 61; Lu \& Abeysekera, 2014: 428). The stakeholder theory suggests that firm activities should be approved by stakeholders (Liu \& Anbumozhi, 2009: 594). Firms disclose environmental information to meet the stakeholder demands (Dejean, 2009: 61). However, while legitimacy theory concentrates on the expectations of society in its entirety, stakeholder theory concentrates on specific interest groups (stakeholders), e.g. shareholders, creditors, employees, government, customers and suppliers (Lu \& Abeysekera, 2014: 428; Braam et al., 2016). In the framework of information cost theory, the environmental disclosure decisions are subject to a trade-off between the benefits and costs of information disclosure (Dejean, 2009: 61). Firms disclose more information when benefits exceed costs. A Part of these costs is related to collating, confirming, measuring and publishing information (Brammer \& Pavelin, 2006: 1171). Furthermore, proprietary costs could be incurred when firms disclose private information. Managers do not disseminate private information that could be used by stakeholders and negatively affects the firm's value (Cormier \& Gordon, 2001: 592; Guidry \& Patten, 2012: 83). For example, environmental groups may use private information related to environment to start investigations against the 
company (Guidry \& Patten, 2012: 83); Competitors could use the private information to enhance their competitive situation (Cormier \& Gordon, 2001: 593).

Prior empirical researches have extensively investigated the determinants of environmental disclosure. Some studies focused on the importance of corporate environmental disclosure as a determinant of financial performance. However, in Turkey, environmental disclosure has received little attention in previous researches, especially regarding its effect on financial performance. We contribute to the existing literature by investigating the determinants of environmental disclosure and its impact on financial performance for a sample of listed Turkish firms. This study attempts to answer two questions. The first is: how do firm size, financial leverage, profitability, industry type, information asymmetry, investment opportunities, equity agency costs and business risk affect the probability that the firm will disclose environmental information? The second is: how does environmental disclosure affect the financial performance? This study investigates the effect of factors (investment opportunities, efficiency ratio and business risk) that have not been considered in previous studies performed in Turkey. Moreover, the period covered in this study is somewhat different (2014-2018).

The remainder of this paper is organized as follows. The next section discusses the literature and hypotheses. Section 3 describes data and methodology. Empirical results are presented in section 4 . Section 5 summarizes the findings.

\section{Literature Review and Hypotheses Development}

\subsection{The Determinants of Environmental Disclosure}

In order to answer the first question, hypotheses are developed based on the theoretical framework and previous empirical studies that focused on the firm's characteristics as factors affecting the environmental disclosure. The study investigates the effects of the following firm's characteristics: firm size, financial leverage, profitability, industry type, information asymmetry, investment opportunities, equity agency costs and business risk.

\subsubsection{Firm Size}

According to the legitimacy theory and stakeholder theory, larger firms are more visible and tend to disclose more information to legitimize their operations and activities, and to meet the expectations of society and stakeholders. Compared to small firms, larger firms are subject to increased pressure from society. These pressures push larger firms to disclose more environmental information than small firms (Rover et al., 2015: 9; Andrikopoulos \& Kriklani, 2013: 58; Brammer \& Pavelin, 2006: 1173; da Silva Monteiro \& Aibar-Guzmán, 2010: 188). Moreover, the accumulating and publishing of environmental information is less costly for larger firms (Pahuja, 2009: 232). Larger firms have more ability and sufficient resources to afford the costs of producing information (Welbeck et al., 2017: 3; De'Jean \& Martinez, 2009: 63). The results of most previous studies confirmed the positive relation between firm size and environmental disclosure (e.g. Deegan \& Gordon, 
Kalash, I. (2020), "Environmental Disclosure: Determinants and Effects on Financial

Performance? An Empirical Evidence from Turkey", Sosyoekonomi, Vol. 28(46), 95-115.

1996; Neu et al., 1998; Patten, 2002; Freedman \& Jaggi, 2005; De'Jean \& Martinez, 2009; da Silva Monteiro \& Aibar-Guzmán, 2010; Huang \& Kung, 2010; Clarkson et al., 2011; Michelon \& Parbonetti, 2012; Andrikopoulos \& Kriklani, 2013; Sulaiman et al., 2014; Akbaş, 2014; Fontana et al., 2015; Silva da ROSA et al., 2015; Braam et al., 2016; Akrout \& Othman, 2016; Giannarakis et al., 2017; Vogt et al., 2017; Deswanto \& Siregar, 2018; Lu \& Taylor, 2018; Odoemelam \& Okafor, 2018; Wang \& Zhang, 2019; Ashfaq \& Rui, 2019; Akbaş \& Canikli, 2019). However, Al-Tuwaijri et al. (2003), and Yildiz et al. (2016) found a negative relation between firm size and environmental disclosure. On the other hand, Guidry \& Patten (2012), Juhmani (2014), and Elshabasy (2018) have shown an insignificant relationship.

According to the previous discussion, firm size (as proxied by the size of total assets) could has positive effect on environmental disclosure. In other words, it is expected that large firms will tend to disclose more environmental information than small firms. Hence, the first hypothesis is as follows:

H1: Environmental disclosure is positively related to firm size.

\subsubsection{Financial Leverage}

Firms can alleviate the conflicts of interests between debtholders and shareholders by disclosing more information. Highly leveraged firms tend to disclose more environmental information in order to satisfy debtholders and gain their confidence, and to provide evidence that firm's projects are not so risky (Rover et al., 2015: 10; Kouloukoui et al., 2019: 4; Freedman \& Jaggi, 2005: 220). Furthermore, Environmental disclosure mitigates the concerns about the transfer of wealth from debtholders to shareholders (Rover et al., 2015: 10; Kouloukoui et al., 2019: 4). Fonseka et al. (2019) and Luo et al. (2019) found that environmental disclosures result in lower debt costs. Put together, environmental disclosure contributes to low cost of capital by reducing the agency costs of debt and information asymmetry. Hence, high financial leverage will encourage firms to disclose more environmental information. The results of several studies provide support for this expectation (Clarkson et al., 2008; Huang \& Kung, 2010; Zeng et al., 2012; Guidry \& Patten, 2012; Juhmani, 2014; Sulaiman et al., 2014; Yildiz et al., 2016; Ismail et al., 2018; Kolsi \& Attayah, 2018). Accordingly, we state the following hypothesis:

H2a: There is a positive relationship between financial leverage and environmental disclosure.

Contradicting the previous view, highly leveraged firms may face difficulties to provide the required funds for environmental disclosure (Andrikopoulos \& Kriklani, 2013: 59; Brammer \& Pavelin, 2006: 1174). These firms may not have the ability to trade off the benefits from environmental disclosure against the information costs ( $\mathrm{Lu} \&$ Abeysekera, 2014: 429). Therefore, highly leveraged firms will disclose less information. Some studies supported this view and found a negative relation between financial leverage and environmental disclosure (Brammer \& Pavelin, 2006; Dejean, 2009; Andrikopoulos \& 
Kriklani, 2013; Singhania \& Gandhi, 2015; Deswanto \& Siregar, 2018; Kouloukoui et al., 2019). However, another empirical research group did not find any significant relation between financial leverage and environmental disclosure (Cormier \& Gordon, 2001; Freedman \& Jaggi, 2005; Brammer \& Pavelin, 2008; Pahuja, 2009; Sun et al., 2010; Clarkson et al., 2011; Michelon \& Parbonetti, 2012; Wang et al., 2012; Setyorini \& Ishak, 2012; Lu \& Abeysekera, 2014; Akbaş, 2014; Rover et al., 2015; Braam et al., 2016; Ahmadi \& Bouri, 2017; Chandok \& Singh, 2017; Elshabasy, 2018; Kılıç \& Kuzey, 2019; Akbaş \& Canikli, 2019). From the discussion above, we propose the following hypothesis:

H2b: There is a negative relationship between financial leverage and environmental disclosure.

\subsubsection{Profitability}

The previous studies produced mixed results on the relation between profitability and environmental disclosure. While some studies showed a negative relationship (Huang \& Kung, 2010; Andrikopoulos \& Kriklani, 2013; Akbaş, 2014; Chandok \& Singh, 2017), several studies failed to find any association between profitability and environmental disclosure (e.g. Hackston \& Milne, 1996; Cormier \& Gordon, 2001; Brammer \& Pavelin, 2008; Liu \& Anbumozhi, 2009; Sun et al., 2010; Clarkson et al., 2011; Zeng et al., 2012; Sulaiman et al., 2014; Juhmani, 2014; Akrout \& Othman, 2016; Yildiz et al., 2016; Welbeck et al., 2017; Vogt et al., 2017; Deswanto \& Siregar, 2018; Kolsi \& Attayah, 2018; Kılıç \& Kuzey, 2019). However, some studies found that increases in profitability contribute to more transparency in environmental issues (Pahuja, 2009; Setyorini \& Ishak, 2012; Singhania \& Gandhi, 2015; Braam et al., 2016; Ahmadi \& Bouri, 2017; Giannarakis et al., 2017; Ismail et al., 2018; Elshabasy, 2018; Kouloukoui et al., 2019; Wang \& Zhang, 2019). The reason for the positive relation between profitability and environmental disclosure is that more profitable firms have more ability to fund the costs of environmental reporting (Freedman \& Jaggi, 2005: 221; Brammer \& Pavelin, 2006: 1174; Andrikopoulos \& Kriklani, 2013: 59). Moreover, high profitability could exacerbate the shareholders-managers agency conflicts (Jensen, 1986). These conflicts could be mitigated by disclosing more information. These arguments lead to the third hypothesis:

H3: Environmental disclosure is positively related to profitability.

\subsubsection{Industry Type}

Firms belonging to environmentally sensitive Industries (e.g. manufacturing firms) disclose more environmental information. The operations of these firms have high negative effects on environment and are subject to more stakeholder pressure related to environmental issues (Brammer \& Pavelin, 2008: 123). By paying more attention to environmental transparency, firms operating in environmentally sensitive industries legitimize their operations and improve their image (Deegan \& Gordon, 1996: 194). Several studies have found that firms in environmentally sensitive industries disseminate more environmental information (e.g. Hackston \& Milne, 1996; Patten, 2002; Brammer \& Pavelin, 2006; Liu \& 
Anbumozhi, 2009; Huang \& Kung, 2010; Wang et al., 2012; Lu, 2014; Akbaş, 2014; Fontana et al., 2015; Welbeck et al., 2017; Ismail et al., 2018; Ofoegbu et al., 2018; Ashfaq \& Rui, 2019). However, some studies reported an insignificant relation between industry type and environmental disclosure (Braam et al., 2016; Ahmadi \& Bouri, 2017; Kolsi \& Attayah, 2018; Odoemelam \& Okafor, 2018; Kılıç \& Kuzey, 2019; Akbaş \& Canikli, 2019; Kouloukoui et al., 2019).

Based on previous results and literature, the fourth hypothesis is stated as follows:

H4: Environmentally sensitive firms disclose more environmental information than environmentally non-sensitive firms.

\subsubsection{Information Asymmetry}

One of the most important benefits of disclosing environmental information is reducing the information asymmetry. Information asymmetry problem appears when managers have more information than investors. The cost of capital increases under conditions of high information asymmetry because investors lower the value of stocks or require higher interest rate on debt. Therefore, environmental disclosure could be one of the important ways that enable firms to reduce the cost of capital as environmental disclosure can lower the information asymmetry and satisfy investors' needs. In other words, firms with more information asymmetry will disclose more environmental information to lower the financing costs (Cormier \& Gordon, 2001: 593; Clarkson et al., 2008: 314). Clarkson et al. (2008), Clarkson et al. (2011) and Sutantoputra et al. (2012) investigated the effect of stock return volatility (a proxy for information asymmetry) on environmental disclosure. The results showed insignificant relationship. However, Guidry \& Patten (2012) and Ahmadi \& Bouri (2017) found that stock return volatility negatively affects the extent of environmental disclosure. Other studies investigated the relation between earnings management (which is one aspect of the information asymmetry problem) and environmental disclosure. For example, Sun et al. (2010) did not find significant relation between discretionary accruals and environmental disclosure. Setyorini \& Ishak (2012) found that discretionary accruals positively affect the environmental disclosure.

According to the theoretic arguments, the fifth hypothesis is stated as follows:

H5: Environmental disclosure is positively related to information asymmetry.

\subsubsection{Investment Opportunities}

The pecking order theory (discussed by Myers (1984)) suggests that the costs associated with information asymmetry lead firms to finance their investments firstly with internal funds, then with debt and as a last resort, with equity. Accordingly, firms with more investment opportunities tend to depend more on external finance if internal finance is not sufficient. Under external finance, firms incur costs related to information asymmetry (Myers, 1984: 581). Therefore, it is expected that firms with more investments will disclose 
more environmental information to decrease the asymmetric information costs. Rover et al. (2015: 10) argue that by disclosing more information, a firm with higher growth opportunities earns investors' confidence and desire in financing its projects. Clarkson et al. (2008: 315) state that firms with more capital expenditures may have newer equipment and tend to disclose more information to show their environmental quality. The results of Clarkson et al. (2008), Clarkson et al. (2011) and Sutantoputra et al. (2012) are in line with the previous view. According to the discussion above, we propose the sixth hypothesis as follows:

H6: Environmental disclosure is positively related to investment opportunities.

\subsubsection{Equity Agency Costs}

Agency costs arising from shareholders-managers agency conflicts (discussed by Jensen \& Meckling (1976)), could be decreased by disclosing more information since this information mitigates the shareholders' suspicions that managers will waste the firm resources on bad projects. Therefore, more environmental information will be disclosed in the presence of shareholders-managers agency problem. This view leads us to the seventh hypothesis:

H7: Environmental disclosure is positively related to equity agency costs.

\subsubsection{Business Risk}

Investors' uncertainty regarding firm's value increases with business risk and leads to higher cost of capital. Firms can reduce this uncertainty by providing more information (Connors \& Johnston, 2013: 13; Cormier et al., 2005: 16). Toms (2002: 263) argues that the level of general risk could accentuate the pressures on managers to invest in environmental projects because these investments may be perceived as risk reducing. The results of Toms (2002) indicated that high systematic risk has negative impact on firm's environmental reputation. According to these arguments, it is expected that risky firms will disclose more environmental information to improve their environmental reputation and to reduce the cost of capital associated with uncertainty. Consistent with this expectation, Cormier et al. (2005) reported a positive relation between beta coefficient and environmental disclosure quality. However, Michelon \& Parbonetti (2012), Shan \& Taylor (2014) and Chandok \& Singh (2017) found that systematic risk is not related to environmental reporting.

Based on the previous arguments, we propose the eighth hypothesis as follows:

H8: Environmental disclosure is positively related to business risk.

\subsection{Environmental Disclosure and Financial Performance}

The previous literature suggested that environmental disclosure reduces the asymmetric information costs, agency costs and the cost of capital. Firms legitimize their activities to stakeholders by disclosing environmental information (Cormier \& Gordon, 
2001: 589). This legitimization may increase sales and decrease cost of capital because consumers and investors prefer firms with good environmental reputation (Clarkson et al., 2013: 414; Dhaliwal et al., 2011: 62). Plumlee et al. (2015) indicated that voluntary environmental disclosure is related to firm value through cash flows and cost of equity.

The previous arguments lead us to conclude that environmental information disclosures enhance firm's financial performance. The prior empirical studies provide mixed results about this issue. Li et al. (2018), and Aboud \& Diab (2018) found that environmental, social, and governance (ESG) disclosures have positive impact on firm value. Similarly, the results of Minutolo et al. (2019) indicated that (ESG) disclosures enhance firm value and return on assets. Clarkson et al. (2013) found that environmental disclosure positively affects return on assets while Longoni \& Cagliano (2018) found a positive relation between environmental disclosure and return on investment. Lemma et al. (2018) showed that environmental disclosures reduce the cost of capital. Hassan \& Romilly (2018) and Hassan (2018) indicated that economic performance and firm value are positively associated with environmental disclosure. Yin et al. (2019) found that environmental disclosure positively affects the return on equity. Khlif et al. (2015) investigated the relation between social and environmental disclosure and firm value in two countries (South Africa and Morocco). They found that social and environmental disclosures significantly and positively affect the firm value only in South African sample. In contrast, Mathuva \& Kiweu (2016) document a negative relation between social and environmental disclosure and both return on assets and return on equity. Li et al. (2017) reported similar findings. However, other studies found that environmental disclosures do not affect the financial performance (Qiu et al., 2016; Kolsi \& Attayah, 2018; Lu \& Taylor, 2018; Deswanto \& Siregar, 2018).

According to the theoretic arguments and the results of previous studies, we propose the ninth hypothesis as follows:

H9: There is a positive relation between environmental disclosure and financial performance.

\section{Data and Methodology}

\subsection{Sample Selection}

Based on the availability of financial data, our analysis is performed on 66 firms listed on Istanbul Stock Exchange during the period 2014-2018. Firms included in sample are selected from $\mathrm{CDP}^{2}$ Turkey climate change reports ${ }^{3}$. The sample consists of two groups. The

CDP, formerly the Carbon Disclosure Project, asks firms to disclose information on their environmental performance, and measures firms' environmental performance according to the provided information $<$ www.cdp.net>, 23.07.2019.

3 CDP Turkey climate change reports are available on $<w w w . c d p t u r k e y . s a b a n c i u n i v . e d u>, 23.07 .2019$. 
first group ( $\mathrm{G} 1=36$ firms) represents firms that have disclosed environmental information to CDP (according to CDP Turkey climate change reports). The second group (G2=30 firms) represents firms that are requested to disclose information to CDP and fail to do so or have not provided sufficient environmental information to CDP to be evaluated ${ }^{4}$. Most firms in the sample are listed on BIST-100 index. Financial data related to firms are collected from the website <www.kap.org.tr>. Stock prices are obtained from <www.finance.yahoo.com>. The resulting unbalanced total panel data provide 285 firm-year observations.

\subsection{Research Models and Variables Definition}

\subsubsection{Dependent Variable: Environmental Disclosure (ED)}

Some previous studies (Akbaş, 2014; Yildiz et al., 2016) that investigated the determinants of environmental disclosure of Turkish firms have measured the degree of environmental disclosure by using “content analysis”. However, Kılıç \& Kuzey (2019) and Akbaş \& Canikli (2019) have used another method which mainly depends on firms' response to the CDP-Turkey questionnaire. In this article, the CDP Turkey climate change reports were used to measure the dependent variable (environmental disclosure - ED), which is a binary variable takes a value of one if a firm $i$ in period $t$ belongs to $\mathrm{G} 1$ (a firm that disclosed environmental information), and takes a value of zero if a firm $\mathrm{i}$ in period $\mathrm{t}$ belongs to $\mathrm{G} 2$ (a firm that failed to disclose environmental information).

\subsubsection{Model Related to the Factors Affecting the Environmental Disclosure}

Because of the binary character of the dependent variable, we use a binary logistic regression model to test the hypotheses related to the first question. The model predicts whether the firm characteristics will affect the probability that the firm will disclose environmental information (the firm will belong to G1). The model is estimated as follows:

$$
\begin{aligned}
& \operatorname{logit}(y)=\ln \left(\frac{\pi}{1-\pi}\right)=a+\beta_{1}\left(\text { Size }_{i t}\right)+\beta_{2}\left(\text { Lev }_{i t}\right)+\beta_{3}\left(R O A_{i t}\right)+\beta_{4}\left(I N D_{i t}\right)+ \\
& \beta_{5}\left(S R V_{i t}\right)+\beta_{6}\left(I N V_{i t}\right)+\beta_{7}\left(E R_{i t}\right)+\beta_{8}\left(\text { Risk }_{i t}\right)
\end{aligned}
$$

Where:

$\boldsymbol{Y}$ : is a dummy variable and represents environmental disclosure (ED).

$\pi$ : is the probability that the firm will disclose environmental information.

Size: is firm size, computed as the natural logarithm of total assets. 
Lev: is financial leverage, computed as the ratio of total debt to total assets.

ROA: is return on assets, measured as the ratio of net profits to total assets.

IND: is a dummy variable set to one if the firm belongs to environmentally sensitive industry (manufacturing firm), and 0 otherwise.

SRV: is stock return volatility, computed as the standard deviation of adjusted monthly stock returns during a year (Clarkson et al., 2008). SRV represents a variable proxying for information asymmetry (Lim, 2001: 377; Clarkson et al., 2008: 314; Clarkson et al., 2011: 39). Lim (2001: 377) argues that earnings uncertainty increases when firms disclose less information.

INV: is investment opportunities, computed as (total assets $\mathrm{t}_{\mathrm{t}}$ - total assets $\mathrm{t}_{\mathrm{t}-1}$ ) / (total assets ${ }_{\mathrm{t}}$ ). (Fama \& French, 2002: 8).

ER: is efficiency ratio, computed as the ratio of sales to total assets. This ratio is the proxy of equity agency costs. Efficiency ratio is inversely related to equity agency costs. Efficiency decreases when managers invest in negative-net present value projects that result in lower revenues (Ang et al., 2000: 86). Therefore, decreases in efficiency ratio exacerbate the shareholders-managers agency conflicts.

Risk: is business risk, computed as the absolute value of percent variation in earnings before interest and taxes.

\subsubsection{Models Related to the Effect of Environmental Disclosure on Financial Performance}

Previous studies used different measures of financial performance (e.g. Tobin's Q, stock price, return on assets, return on equity, return on sales). We use four measures of financial performance as dependent variable (return on assets, return on equity, operating profit margin and stock returns). We estimate the following ordinary least squares (OLS) regressions to determine the effect of environmental disclosure on financial performance:

$$
\begin{aligned}
& R O A_{i t}=\beta_{0}+\beta_{1}\left(E D_{i t}\right)+\beta_{2}\left(\text { Size }_{i t}\right)+\beta_{3}\left(S G_{i t}\right)+\beta_{4}\left(\text { Lev }_{i t}\right)+\varepsilon_{i t} \\
& R O E_{i t}=\beta_{0}+\beta_{1}\left(E D_{i t}\right)+\beta_{2}\left(\text { Size }_{i t}\right)+\beta_{3}\left(S G_{i t}\right)+\beta_{4}\left(\text { Lev }_{i t}\right)+\varepsilon_{i t} \\
& O P M_{i t}=\beta_{0}+\beta_{1}\left(E D_{i t}\right)+\beta_{2}\left(\text { Size }_{i t}\right)+\beta_{3}\left(S G_{i t}\right)+\beta_{4}\left(\text { Lev }_{i t}\right)+\varepsilon_{i t} \\
& S R_{i t}=\beta_{0}+\beta_{1}\left(E D_{i t}\right)+\beta_{2}\left(\text { Size }_{i t}\right)+\beta_{3}\left(S G_{i t}\right)+\beta_{4}\left(\text { Lev }_{i t}\right)+\varepsilon_{i t}
\end{aligned}
$$

Where:

ROE: is return on equity, measured as the ratio of net profits to equity. 
OPM: is operating profit margin, measured as the ratio of earnings before interest and taxes to sales.

SR: is stock returns, measured as the average of adjusted monthly stock returns during a year.

SG: is sales growth, computed as the percent variation in sales.

Firm size (Size), sales growth (SG) and financial leverage (Lev) are used as control variables.

\section{Results}

\subsection{Descriptive Statistics and Correlation Matrix}

Table 1 presents the descriptive statistics for the variables included in our analysis. The table shows that firms have high financial leverage; on average $60.5 \%$ of total assets are financed by debt. The performance measures of the sample firms are relatively low; the mean values of ROA, ROE, OPM and SR are 4.8\%, 8.2\%, 16.5\%, 1.7\% respectively. The efficiency ratio is also relatively low; on average 0.89 . Firms have a mean sales growth of $20.2 \%$, and a mean investment growth of $14.5 \%$.

Table: 1

\section{Descriptive Statistics}

\begin{tabular}{|c|c|c|c|c|c|c|}
\hline & Mean & Median & Std. Deviation & Minimum & Maximum & Observations \\
\hline Size & 22.255 & 22.060 & 1.854 & 18.520 & 26.710 & 285 \\
\hline Lev & 0.605 & 0.640 & 0.222 & 0.080 & 0.980 & 285 \\
\hline SRV & 0.101 & 0.086 & 0.073 & 0.000 & 0.753 & 278 \\
\hline INV & 0.145 & 0.143 & 0.143 & -0.538 & 0.810 & 285 \\
\hline ER & 0.892 & 0.723 & 0.813 & 0.050 & 5.000 & 280 \\
\hline Risk & 0.848 & 0.365 & 1.444 & 0.001 & 9.916 & 278 \\
\hline ROA & 0.048 & 0.045 & 0.099 & -0.354 & 0.995 & 285 \\
\hline ROE & 0.082 & 0.116 & 0.274 & -1.558 & 1.101 & 283 \\
\hline OPM & 0.165 & 0.112 & 0.249 & -2.558 & 0.872 & 283 \\
\hline SR & 0.017 & 0.012 & 0.065 & -0.142 & 0.721 & 280 \\
\hline SG & 0.202 & 0.189 & 0.261 & -1.000 & 1.864 & 282 \\
\hline
\end{tabular}

Table 2 reports the Spearman rank correlation coefficients between variables. We find in panel A that firm size and financial leverage are significantly and positively related to environmental disclosure (ED). Moreover, the correlation coefficients for industry type, efficiency ratio and business risk are negative and significant, while stock return volatility and investment opportunities are not significant. However, the results of industry type, stock return volatility and investment opportunities are inconsistent with predictions. In Table 2, panel B provides mixed results about the relation between environmental disclosure and financial performance. While return on assets $(-0.185)$ and operating profit margin $(0.186)$ are significantly associated with (ED), return on equity and stock returns are insignificant. However, these correlations are between two variables and do not consider the effects of other variables, and do not take into account the causality. Regression models would provide more accurate results. Table 2 also shows that the correlation coefficients are relatively low, indicating the absence of multicollinearity problem. 
Table: 2

Correlation Matrix

\begin{tabular}{|c|c|c|c|c|c|c|c|c|}
\hline \multicolumn{9}{|c|}{ Panel A: Correlations between the firm characteristics and environmental disclosure } \\
\hline & ED & Size & Lev & IND & SRV & INV & ER & Risk \\
\hline ED & 1 & & & & & & & \\
\hline Size & $0.329 * *$ & 1 & & & & & & \\
\hline Lev & $0.380^{* * *}$ & $0.436 * *$ & 1 & & & & & \\
\hline IND & $-0.150^{*}$ & $-0.410^{* * *}$ & $-0.467 * *$ & 1 & & & & \\
\hline SRV & 0.100 & -0.098 & 0.088 & -0.028 & 1 & & & \\
\hline INV & 0.049 & $0.174 * *$ & 0.066 & -0.097 & 0.030 & 1 & & \\
\hline ER & $-0.305 * *$ & $-0.370^{* * *}$ & $-0.209 * *$ & $0.334 * *$ & $-0.252^{* *}$ & -0.089 & 1 & \\
\hline Risk & $-0.132 *$ & $-0.176^{* *}$ & -0.044 & 0.031 & $0.137^{*}$ & 0.099 & 0.048 & 1 \\
\hline \multicolumn{9}{|c|}{ Panel B: Correlations between environmental disclosure and financial performance } \\
\hline & \multirow{2}{*}{\multicolumn{2}{|c|}{$\begin{array}{c}\text { ED } \\
1\end{array}$}} & ROA & & OPM & \multirow{2}{*}{\multicolumn{2}{|c|}{ SR }} \\
\hline ED & & & & \multicolumn{2}{|l|}{ ROE } & & & \\
\hline ROA & \multicolumn{2}{|l|}{$\frac{1}{-0.185^{* *}}$} & 1 & & & & & \\
\hline ROE & \multicolumn{2}{|l|}{$\frac{-0.185^{* *}}{-0.015}$} & $0.878^{* * *}$ & \multicolumn{2}{|l|}{1} & & & \\
\hline OPM & \multicolumn{2}{|l|}{$0.186 * *$} & $0.241^{* * *}$ & \multicolumn{2}{|l|}{$0.319 * *$} & 1 & & \\
\hline SR & \multicolumn{2}{|l|}{-0.079} & $0.187^{* * *}$ & \multicolumn{2}{|l|}{$0.217^{* *}$} & 0.013 & \multicolumn{2}{|c|}{1} \\
\hline
\end{tabular}

$* P<0.05, * * P<0.01$.

\subsection{Binary Logistic Regression Results}

Table 3 and Table 4 show the results of binary logistic regression. In Table 3, we find that firm size and financial leverage positively and significantly affect the probability that the firm will disclose environmental information. These results indicate that larger firms and firms with more financial leverage are more likely to disclose environmental information (i.e. are more likely to be in G1). The result regarding firm size is consistent with the legitimacy, stakeholder and information cost theories; where larger firms are more visible and tend to legitimize their activities to society and stakeholders by disclosing more information. Moreover, disclosures are less costly for larger firms, as these firms incur less costs and have more capacity and resources to accumulate, produce and publish environmental information (Pahuja, 2009: 232; De'Jean \& Martinez, 2009: 63; Welbeck et al., 2017: 3). The positive relation between firm size and ED is in line with the findings of most prior studies. The result related to financial leverage is consistent with the assumption that highly leveraged firms are more susceptible to the agency costs of debt and tend to disclose more information to reduce the cost of debt. This result is compatible with several previous studies (e.g. Clarkson et al., 2008; Zeng et al., 2012; Sulaiman et al., 2014; Yildiz et al., 2016; Ismail et al., 2018).

We also find that efficiency ratio has significant negative effect on firm's propensity to disseminate environmental information. Agency costs of equity are more pronounced among firms with low efficiency ratio. Therefore, these firms tend to disclose more information to reduce the costs of capital. The remaining variables (ROA ${ }^{5}$, IND, SRV, INV and Risk) have insignificant effect on the possibility that the firm will disclose

5 We replace ROA with a market-based performance measure (stock returns). However, the coefficient on stock returns (SR) is also insignificant. 
environmental information. According to these results, the hypotheses $\mathrm{H} 1, \mathrm{H} 2 \mathrm{a}$ and $\mathrm{H} 7$ cannot be rejected. On the other hand, hypotheses $\mathrm{H} 2 \mathrm{~b}, \mathrm{H} 3, \mathrm{H} 4, \mathrm{H} 5, \mathrm{H} 6$ and $\mathrm{H} 8$ are rejected.

Table: 3

The Determinants of Environmental Disclosure

\begin{tabular}{|c|c|c|}
\hline Model & Predicted Sign & Dependent Variable: ED \\
\hline Constant & & $\begin{array}{l}-5.8^{* *} \\
(0.018) \\
\end{array}$ \\
\hline Size & + & $\begin{array}{l}0.187^{*} \\
(0.077)\end{array}$ \\
\hline Lev & ? & $\begin{array}{c}3.637 * * * \\
(0.000) \\
\end{array}$ \\
\hline ROA & + & $\begin{array}{c}1.147 \\
(0.634) \\
\end{array}$ \\
\hline IND & + & $\begin{array}{c}0.084 \\
(0.812)\end{array}$ \\
\hline SRV & + & $\begin{array}{c}2.214 \\
(0.278) \\
\end{array}$ \\
\hline INV & + & $\begin{array}{l}-0.601 \\
(0.614) \\
\end{array}$ \\
\hline ER & - & $\begin{array}{c}-0.963 * * * \\
(0.001) \\
\end{array}$ \\
\hline Risk & + & $\begin{array}{l}-0.071 \\
(0.467)\end{array}$ \\
\hline Cox \& Snell $\mathrm{R}^{2}$ & & 0.242 \\
\hline Nagelkerke $\mathbf{R}^{2}$ & & 0.323 \\
\hline Chi-square & & $\begin{array}{c}73.719 \text { **** } \\
(0.000)\end{array}$ \\
\hline Number of observations & & 266 \\
\hline
\end{tabular}

This table presents the binary logistic regression results for factors affecting the environmental disclosure.

$P$ values are reported in parentheses.

$*, * *, * * *$, indicate significance at the $10 \%, 5 \%, 1 \%$ levels, respectively.

Table: 4

\section{Classification Table}

\begin{tabular}{|l|c|c|c|c|}
\hline \multirow{2}{*}{ Observed } & \multicolumn{2}{|c|}{ Predicted } \\
\cline { 2 - 4 } \multicolumn{2}{c|}{} & \multicolumn{2}{|c|}{ ED } & \multicolumn{2}{c|}{ Percentage Correct } \\
\cline { 2 - 5 } \multirow{2}{*}{ ED } & 0 & 104 & 35 & 74.8 \\
\cline { 2 - 5 } & 1 & 41 & 86 & 67.7 \\
\hline Overall Percentage & & & & 71.4 \\
\hline
\end{tabular}

Table 4 shows the predictive accuracy of the model. For example, we see that 35 cases of second group of our sample $\mathrm{G} 2(\mathrm{ED}=0)$ are predicted as value 1 while their actual value is 0 . In the same way, 41 cases of the first group $\mathrm{G} 1(\mathrm{ED}=1)$ are predicted as value 0 while their actual value is 1 . However, the overall predictive accuracy percentage is 71.4, which indicates that $71.4 \%$ of the cases are correctly predicted by the logistic regression model.

\subsection{Results of The OLS Regression Models}

Table 5 presents the OLS estimation results for the effect of environmental disclosure on financial performance as proxied by return on assets (ROA), return on equity (ROE), operating profit margin (OPM) and stock returns (SR). 


\section{Table: 5}

The Effect of Environmental Disclosure on Financial Performance

\begin{tabular}{|c|c|c|c|c|}
\hline \multirow{2}{*}{ Models } & \multicolumn{4}{|c|}{ Dependent Variable } \\
\hline & ROA & ROE & OPM & SR \\
\hline Constant & $\begin{array}{c}0.082 \\
(0.120)\end{array}$ & $\begin{array}{c}-0.358^{*} \\
(0.063)\end{array}$ & $\begin{array}{c}-0.832 * * * \\
(0.000)\end{array}$ & $\begin{array}{c}0.113^{* *} * \\
(0.023)\end{array}$ \\
\hline ED & $\begin{array}{c}-0.006 \\
(0.504)\end{array}$ & $\begin{array}{c}0.006 \\
(0.866)\end{array}$ & $\begin{array}{c}0.046 * * \\
(0.036)\end{array}$ & $\begin{array}{c}-0.013 \\
(0.146)\end{array}$ \\
\hline Size & $\begin{array}{c}0.003 \\
(0.194)\end{array}$ & $\begin{array}{c}0.032 * * * \\
(0.001)\end{array}$ & $\begin{array}{c}0.047^{* * *} \\
(0.000)\end{array}$ & $\begin{array}{c}-0.005 * * \\
(0.041)\end{array}$ \\
\hline SG & $\begin{array}{c}0.063 * * * \\
(0.000)\end{array}$ & $\begin{array}{l}0.152 * * \\
(0.011)\end{array}$ & $\begin{array}{c}0.07 * \\
(0.086)\end{array}$ & $\begin{array}{c}-0.015 \\
(0.321)\end{array}$ \\
\hline Lev & $\begin{array}{c}-0.201 * * * \\
(0.000)\end{array}$ & $\begin{array}{c}-0.498 * * * \\
(0.000)\end{array}$ & $\begin{array}{c}-0.109^{* *} * \\
(0.044)\end{array}$ & $\begin{array}{c}-0.038 * \\
(0.071)\end{array}$ \\
\hline Adjusted $\mathbf{R}^{2}$ & 0.269 & 0.126 & 0.223 & 0.02 \\
\hline $\mathbf{F}$ & $\begin{array}{c}26.827 * * * \\
(0.000)\end{array}$ & $\begin{array}{c}11.032 * * * \\
(0.000)\end{array}$ & $\begin{array}{c}21.092 * * * \\
(0.000)\end{array}$ & $\begin{array}{l}2.384^{*} \\
(0.052)\end{array}$ \\
\hline Number of observations & 282 & 280 & 281 & 277 \\
\hline
\end{tabular}

This table presents the OLS estimation results for the effect of environmental disclosure on financial performance. $P$ values are reported in parentheses.

$*, * *, * * *$, indicate significance at the $10 \%, 5 \%, 1 \%$ levels, respectively.

We find that environmental disclosure has no significant impact on ROA, ROE and SR. On the other hand, environmental disclosure significantly and positively affects (OPM), indicating that environmental disclosure contributes to better operating profit margin. This result can be explained by the assumption that the legitimization achieved by disclosing environmental information can enhance firm reputation and consumer confidence, leading to increases in sales and operating profits (Clarkson et al., 2013: 414; Dhaliwal et al., 2011: 62). However, the results of table (5) provide a weak evidence that environmental disclosure affects the financial performance. Accordingly, these findings partially support the ninth hypothesis. The insignificant relationship between ED and financial performance measures is consistent with the results of Qiu et al. (2016), Kolsi \& Attayah (2018), Lu \& Taylor (2018) and Deswanto \& Siregar (2018).

\section{Conclusion}

Environmental issues have obtained increased attention around the world because of the catastrophic effects resulting from non-clean production. Society and stakeholders are pressuring firms to provide more information about their activities related to environmental matters. Under these conditions, firms may tend to disclose more environmental information to legitimize their operations, and to reduce the information asymmetry and cost of capital, resulting in better financial performance. In this article, we have attempted to investigate the determinants of environmental disclosure and its effect on financial performance of 66 Turkish firms listed on Istanbul Stock Exchange during the period 2014-2018. We have assumed that firm size, financial leverage, profitability, industry type, information asymmetry, investment opportunities, shareholders-managers agency problem and business risk have impact on the likelihood that the firm will disclose environmental information. Furthermore, it has been hypothesized that environmental disclosure has significant effect on financial performance. 
Using binary logistic and OLS regression models, we have found that highly leveraged and larger firms are more likely to disclose environmental information. Moreover, firms with low efficiency ratio (i.e. firms with high agency costs of equity) have more incentive to disclose environmental information. On the other hand, our results indicated that profitability, industry type, information asymmetry (as proxied by stock return volatility), investment opportunities and business risk do not affect the firm's tendency to disclose environmental information. Regarding the relationship between environmental disclosure and financial performance as proxied by return on assets, return on equity, operating profit margin and stock returns, the results indicated that environmental disclosure has significant positive effect on operating profit margin, but no significant impact on return on assets, return on equity and stock returns.

This article offers insights and implications for different interested groups. The results support the legitimacy theory and stakeholder theory in the Turkish context as firm size has positive effect on ED. Larger firms are more visible and are subject to more pressure from stakeholders, and therefore, it is more important for these firms to legitimize their activities and meet the needs of stakeholders by disclosing environmental information. The positive effect of financial leverage on ED indicates that firms with high possibility of experiencing agency cost of debt are more likely to disclose environmental information. The results also confirm a negative relation between efficiency ratio and $\mathrm{ED}$, indicating that agency costs of equity play significant role in disclosing environmental information. These results offer important message indicating that managers can use environmental disclosure as an important tool to reduce the cost of capital by decreasing the agency costs of debt and equity. The positive effect of ED on OMP supports the legitimacy theory and indicates that managers, by legitimizing their activities through ED, can enhance sales and operating profits. Policymakers and regulators can contribute to better social and economic development by introducing principles and regulations that enhance corporate environmental disclosures and compel firms to disclose detailed information about their environmental performance. These procedures can increase the market efficiency by enhancing the disclosures and information about firms' projects and investments.

This study explored the direct relationship between ED and financial performance. Future studies can investigate this relationship in the presence of other factors such as those that play important role in determining ED. In this context, future research can test whether the significant drivers of ED affect the relationship between ED and financial performance.

\section{References}

Aboud, A. \& A. Diab (2018), "The Impact of Social, Environmental and Corporate Governance Disclosures on Firm Value: Evidence from Egypt”, Journal of Accounting in Emerging Economies, 8(4), 442-458.

Ahmadi, A. \& A. Bouri (2017), "The Relationship Between Financial Attributes, Environmental Performance and Environmental Disclosure", Management of Environmental Quality, 28(4), 490-506. 
Akbaş, H.E. \& S. Canikli (2019), "Determinants of Voluntary Greenhouse Gas Emission Disclosure: An Empirical Investigation on Turkish Firms", Sustainability, 11, 107, 1-24.

Akbaş, H.E. (2014), "Company Characteristics and Environmental Disclosure: An Empirical Investigation on Companies Listed on Borsa Istanbul 100 Index", The Journal of Accounting and Finance, 62, 145-164.

Akrout, M.M. \& H.B. Othman (2016), "Ownership Structure and Environmental Disclosure in Mena Emerging Countries", Corporate Ownership \& Control, 13(4), 381-388.

Al-Tuwaijri, S.A. \& T.E. Christensen \& K.E. Hughes II (2003), “The Relations among Environmental Disclosure, Environmental Performance, and Economic Performance: A Simultaneous Equations Approach", Accounting Organizations and Society, 29(5-6), 447-471.

Andrikopoulos, A. \& N. Kriklani (2013), "Environmental Disclosure and Financial Characteristics of the Firm: The Case of Denmark", Corporate Social Responsibility and Environmental Management, 20, 55-64.

Ang, J.S. \& R.A. Cole \& J.W. Lin (2000), “Agency Costs and Ownership Structure”, The Journal of Finance, 55(1), 81-106.

Ashfaq, K. \& Z. Rui, (2019) "Revisiting the Relationship Between Corporate Governance and Corporate Social and Environmental Disclosure Practices in Pakistan”, Social Responsibility Journal, 15(1), 90-119.

Braam, G. \& L. Uit de Weerd \& M. Hauck \& M. Huijbregts (2016), "Determinants of Corporate Environmental Reporting: the importance of environmental performance and assurance", Journal of Cleaner Production, 129, 724-734.

Brammer, S. \& S. Pavelin (2006), "Voluntary Environmental Disclosures by Large UK Companies", Journal of Business Finance \& Accounting, 33(7-8), 1168-1188.

Brammer, S. \& S. Pavelin (2008), "Factors Influencing the Quality of Corporate Environmental Disclosure", Business Strategy and the Environment, 17(2), 120-136.

Chandok, R. \& S. Singh, (2017)," Empirical Study on Determinants of Environmental Disclosure", Managerial Auditing Journal, 32(4-5), 332-355.

Clarkson, P.M. \& M.B. Overell \& L. Chapple (2011), "Environmental Reporting and its Relation to Corporate Environmental Performance", ABACUS, 47(1), 27-60.

Clarkson, P.M. \& X. Fang \& Y. Li \& G. Richardson (2013), "The Relevance of Environmental Disclosures: Are Such Disclosures Incrementally Informative?", J. Account. Public Policy, 32, 410-431.

Clarkson, P.M. \& Y. Li \& G.D. Richardson \& F.P. Vasvari (2008), "Revisiting the relation between environmental performance and environmental disclosure: An empirical analysis", Accounting, Organizations and Society, 33, 303-327.

Connors, E. \& H.H. Johnston (2013), "Voluntary Environmental Disclosures in 10-Ks and Environmental Reports: Determinants and Relationship to Firm Risk Premium", Semantic Scholar Paper, <http://dx.doi.org/10.2139/ssrn.2345964>, 25.05.2019.

Cormier, D. \& I.M. Gordon (2001), "An examination of social and environmental reporting strategies", Accounting, Auditing \& Accountability Journal, 14(5), 587-616.

Cormier, D. \& M. Magnan \& B.V. Velthoven (2005), "Environmental Disclosure Quality in Large German Companies: Economic Incentives, Public Pressures or Institutional Conditions?", European Accounting Review, 14(1), 3-39. 
da Silva Monteiro, S.M. \& B. Aibar-Guzmán (2010), "Determinants of Environmental Disclosure in the Annual Reports of Large Companies Operating in Portugal", Corporate Social Responsibility and Environmental Management, 17, 185-204.

Deegan, C. \& B. Gordon (1996), "A Study of the Environmental Disclosure Practices of Australian Corporations", Accounting and Business Research, 26(3), 187-199.

Deegan, C. (2002), "The Legitimizing Effect of Social and Environmental Disclosures: A Theoretical Foundation", Accounting, Auditing and Accountability Journal, 15(3), 282311.

Déjean, F. \& I. Martinez (2009), "Environmental Disclosure and the Cost of Equity: The French Case", Accounting in Europe, 6(1), 57-80.

Deswanto, R.B. \& S.V. Siregar (2018), "The Associations Between Environmental Disclosures with Financial Performance, Environmental Performance, and Firm Value”, Social Responsibility Journal, 14(1), 180-193.

Dhaliwal, D.S. \& O.Z. Li \& A. Tsang \& Y.G. Yang (2011), "Voluntary Nonfinancial Disclosure and the Cost of Equity Capital: The Initiation of Corporate Social Responsibility Reporting", The Accounting Review, 86(1), 59-100.

Elshabasy, Y.N. (2018), "The impact of corporate characteristics on environmental information disclosure: an empirical study on the listed firms in Egypt", Journal of Business and Retail Management Research (JBRMR), 12(2), 232-241.

Fama, E.F. \& K.R. French (2002), "Testing trade-off and pecking order predictions about dividends and debt", Review of Financial Studies, 15(1), 1-33.

Fonseka, M. \& T. Rajapakse \& G. Richardson (2019), "The Effect of Environmental Information Disclosure and Energy Product Type on the Cost of Debt: Evidence from Energy Firms in China", Pacific-Basin Finance Journal, 54, 159-182.

Fontana, S. \& E. D'Amico \& D. Coluccia \& S. Solimene (2015), "Does Environmental Performance Affect Companies’ Environmental Disclosure?”, Measuring Business Excellence, 19(3), 42-57.

Freedman, M. \& B. Jaggi (2005), "Global warming, commitment to the Kyoto protocol, and accounting disclosures by the largest global public firms from polluting industries", The International Journal of Accounting, 40, 215-232.

Giannarakis, G. \& E. Zafeiriou \& G. Arabatzis \& X. Partalidou (2017), "Determinants of Corporate Climate Change Disclosure for European Firms", Corporate Social Responsibility and Environmental Management, 25(3), 281-294.

Gray, R. \& M. Javad \& D.M. Power \& C.D. Sinclair (2001), "Social and Environmental Disclosure and Corporate Characteristics: A Research Note and Extension", Journal of Business Finance \& Accounting, 28(3-4), 327-356.

Guidry, R.P. \& D.M. Patten (2012), "Voluntary Disclosure Theory and Financial Control Variables: An Assessment of Recent Environmental Disclosure Research", Accounting Forum, 36, 81-90.

Hackston. D \& M.J. Milne (1996), "Some Determinants of Social and Environmental Disclosures in New Zealand Companies”, Accounting, Auditing \& Accountability Journal, 9(1), 77-108.

Hassan, O. A. G. \& P. Romilly (2018), "Relations Between Corporate Economic Performance, Environmental Disclosure and Greenhouse Gas Emissions: New Insights”, Business Strategy and the Environment, 27(7), 1-17. 
Hassan, O.A.G. (2018), “The Impact of Voluntary Environmental Disclosure on Firm Value: Does Organizational Visibility Play a Mediation Role?", Business Strategy and the Environment, 27(8), 1-14.

Huang, C.L. \& F.H. Kung (2010), "Drivers of Environmental Disclosure and Stakeholder Expectation: Evidence from Taiwan", Journal of Business Ethics, 96, 435-451.

Ismail, A.H. \& A.A.Rahman \& A.A. Hezabr (2018), "Determinants of Corporate Environmental Disclosure Quality of Oil And Gas Industry in Developing Countries", International Journal of Ethics and Systems, 34(4), 527-563.

Jensen, M.C. \& W.H. Meckling (1976), "Theory of the Firm: Managerial Behavior, Agency Costs and Ownership Structure", Journal of Financial Economics, 3(4), 305-360.

Jensen, M.C. (1986), “Agency Costs of Free Cash Flow, Corporate Finance, and Takeovers”, American Economic Review, 76(2), 323-329.

Juhmani, O. (2014), "Determinants of Corporate Social and Environmental Disclosure on Websites: The Case of Bahrain", Universal Journal of Accounting and Finance, 2(4), 77-87.

Khlif, H. \& A. Guidara \& M. Souissi (2015), "Corporate Social and Environmental Disclosure and Corporate Performance: Evidence from South Africa and Morocco", Journal of Accounting in Emerging Economies, 5(1), 51-69.

K1lıç, M. \& C. Kuzey (2019), "The Effect of Corporate Governance on Carbon Emission Disclosures: Evidence from Turkey", International Journal of Climate Change Strategies and Management, 11(1), 35-53.

Kolsi, M.C \& O.F. Attayah (2018), "Environmental Policy Disclosures and Sustainable Development: Determinants, Measure and Impact on Firm Value for ADX Listed Companies", Corporate Social Responsibility and Environmental Management, 25(5), 112.

Kouloukoui, D. \& A.M.O. Sant'Anna \& S.M.S. Gomes et al. (2019), "Factors Influencing the Level of Environmental Disclosures in Sustainability Reports: Case of Climate Risk Disclosure by Brazilian Companies", Corporate Social Responsibility and Environmental Management, 26(4), 1-14.

Lemma, T.T. \& M. Feedman \& M. Mlilo \& J.D. Park (2018), “Corporate Carbon Risk, Voluntary Disclosure, And Cost of Capital: South African Evidence", Business Strategy and the Environment, 28(1), 1-16.

Li, D. \& Y. Zhao \& Y. Sun \& D. Yin (2017), "Corporate Environmental Performance, Environmental Information Disclosure, and Financial Performance: Evidence from China", Human and Ecological Risk Assessment: An International Journal, 23(2), 323 339.

Li, Y. \& M. Gong \& X. Zhang \& L. Koh (2018), "The Impact of Environmental, Social, and Governance Disclosure on Firm Value: The Role of CEO Power", The British Accounting Review, 50(1), 60-75.

Lim, T. (2001), “Rationality and Analysts' Forecast Bias”, The Journal of Finance, 56(1), 369-385.

Liu, X. \& V. Anbumozhi (2009), "Determinant factors of corporate environmental information disclosure: an empirical study of Chinese listed companies", Journal of Cleaner Production, 17, 593-600.

Longoni, A. \& R. Cagliano (2018), "Inclusive Environmental Disclosure Practices and Firm Performance: The Role of Green Supply Chain Management", International Journal of Operations \& Production Management, 38(9), 1815-1835. 
Lu, L.W. \& M.E. Taylor (2018), “A Study of The Relationships Among Environmental Performance, Environmental Disclosure, and Financial Performance", Asian Review of Accounting, 26(1), 107-130.

Lu, Y. \& I. Abeysekera (2014), “Stakeholders' Power, Corporate Characteristics, and Social and Environmental Disclosure: Evidence from China", Journal of Cleaner Production, 64, 426-436.

Luo, W. \& X. Guo \& S. Zhong \& J. Wang (2019), "Environmental Information Disclosure Quality, Media Attention and Debt Financing Costs: Evidence from Chinese heavy polluting listed companies", Journal of Cleaner Production, 231, 268-277.

Mathuva, D.M. \& J.M. Kiweu (2016), "Cooperative Social and Environmental Disclosure and Financial Performance of Savings and Credit Cooperatives in Kenya", Advances in Accounting, incorporating Advances in International Accounting, 35, 197-206.

Michelon, G. \& A. Parbonetti (2012), "The Effects of Corporate Governance on Sustainability Disclosure", Journal of Management and Governance, 16(3), 477-509.

Minutolo, M.C. \& W.D. Kristjanpoller \& J. Stakeley (2019), "Exploring Environmental, Social, and Governance Disclosure Effects on the S\&P 500 Financial Performance", Bus Strat Env, 28(6), 1-13.

Myers, S.C. (1984), “The Capital Structure Puzzle”, Journal of Finance, 39(3), 575-592.

Neu, D. \& H. Warsame \& K. Pedwell (1998), "Managing Public Impressions: Environmental Disclosures in Annual Reports", Accounting, Organizations and Society, 23(3), 265-282.

Odoemelam, N. \& R.G. Okafor (2018), "The Influence of Corporate Governance on Environmental Disclosure of Listed Non-Financial Firms in Nigeria", Indonesian Journal of Sustainability Accounting and Management, 2(1), 25-49.

Ofoegbu, G.N. \& N. Odoemelam \& R.G. Okafor (2018), "Corporate Board Characteristics and Environmental Disclosure Quantity: Evidence from South Africa (Integrated Reporting) and Nigeria (Traditional Reporting)”, Cogent Business \& Management, 5, 1-27.

Pahuja, S. (2009), "Relationship between Environmental Disclosures and Corporate Characteristics: A Study of Large Manufacturing Companies in India”, Social Responsibility Journal, $5(2), 227-244$.

Patten, D.M. (2002), "The Relation Between Environmental Performance and Environmental Disclosure: A Research Note", Accounting, Organizations and Society, 27, 763-7730.

Plumlee, M. \& D. Brown \& R.M. Hayes \& R.S. Marshall (2015), "Voluntary Environmental Disclosure Quality and Firm Value: Further Evidence", J. Account. Public Policy, 34, 336-361.

Qiu, Y. \& A. Shaukat \& R. Tharyan (2016), "Environmental and Social Disclosures: Link with Corporate Financial Performance", The British Accounting Review, 48(1), 102-116.

Rover, S. \& F. Murcia \& F. Murcia (2015), "The Determinants of Social and Environmental Disclosure Practices: The Brazilian Case”, Environmental Quality Management, 25(1), 5-24.

Setyorini, C.T. \& Z. Ishak (2012), "Corporate Social and Environmental Disclosure: A Positive Accounting Theory View Point", International Journal of Business and Social Science, 3(9), 152-164.

Shan, Y.G. \& D. Taylor (2014), "Theoretical Perspectives on Corporate Social and Environmental Disclosure: Evidence from China”, Journal of Asia-Pacific Business, 15(3), 260-281. 
Silva da ROSA, F.S. \& T. Guesser \& N. Hein \& E.D. Pfitscher \& R.J. Lunkes (2015), "Environmental Impact Management of Brazilian Companies: Analyzing Factors That Influence Disclosure of Waste, Emissions, Effluents, and Other Impacts", Journal of Cleaner Production, 96, 148-160.

Singhania, M. \& G. Gandhi (2015), "Social and Environmental Disclosure Index: Perspectives from Indian Corporate Sector", Journal of Advances in Management Research, 12(2), 192208.

Sulaiman, M. \& N. Abdullah \& A.H. Fatima (2014), "Determinants of Environmental Reporting Quality in Malaysia”, International Journal of Economics, Management and Accounting, 22(1), 63-90.

Sun, N. \& A. Salama \& K. Hussainey \& M. Habbash (2010), "Corporate environmental disclosure, corporate governance and earnings management", Managerial Auditing Journal, 25(7), 679-700.

Sutantoputra, A.W. \& M. Lindorff \& E.P. Johnson (2012), "The relationship between environmental performance and environmental disclosure", Australasian Journal of Environmental Management, 19(1), 51-65.

Toms, J.S. (2002), "Firm Resources, Quality Signals and The Determinants of Corporate Environmental Reputation: Some UK Evidence", British Accounting Review, 34, 257 282.

Vogt, M. \& N. Hein \& F. Silva da Rosa \& L. Degenhart (2017), "Relationship between Determinant Factors of Disclosure of Information on Environmental Impacts of Brazilian Companies", Estudios Gerenciales, 33(142), 24-38.

Wang, J. \& B. Zhang (2019), "Quality of Environmental Information Disclosure and Enterprise Characteristics", Management of Environmental Quality, 35(5), 963-979.

Wang, J.L. \& H.H. Hsiung \& W.T. Ku (2012), “Ownership Structure and Environmental Disclosure: Taiwan Evidence", International Research Journal of Finance and Economics", 88, 132144.

Welbeck, E.E. \& G.M.Y. Owusu \& R.A. Bekoe \& J.A. Kusi (2017), "Determinants of Environmental Disclosures of Listed Firms in Ghana", International Journal of Corporate Social Responsibility, 2(11), 1-12.

Yildiz, Ş. \& G. Tuna \& V.E. Tuna (2016), "Relation between Company Features and Environmental Statement within Corporate Social Responsibility: An Application in Chemistry, Petroleum, Rubber and Plastics Products Industry", Journal of Business Research-Türk, 8(2), 255- 276.

Yin, H. \& M. Li \& Y. Ma \& Q. Zhang (2019), "The Relationship between Environmental Information Disclosure and Profitability: A Comparison between Different Disclosure Styles", International Journal of Environmental Research and Public Health, 16, 1-14.

Zeng, S.X. \& X.D. Xu \& H.T. Yin \& C.M. Tam (2012), "Factors that Drive Chinese Listed Companies in Voluntary Disclosure of Environmental Information", J Bus Ethics, 109, 309-321. 
Kalash, I. (2020), "Environmental Disclosure: Determinants and Effects on Financial Performance? An Empirical Evidence from Turkey”, Sosyoekonomi, Vol. 28(46), 95-115.

\section{APPENDIX:}

\section{List of the BIST Codes of Firms Included in the Sample}

\begin{tabular}{|c|c|c|c|}
\hline No & BIST Code & No & BIST Code \\
\hline 1 & AFYON & 34 & PNSUT \\
\hline 2 & AKBNK & 35 & TSKB \\
\hline 3 & AKENR & 36 & YUNSA \\
\hline 4 & ALARK & 37 & AKSA \\
\hline 5 & ALBRK & 38 & AEFES \\
\hline 6 & ARCLK & 39 & AYEN \\
\hline 7 & ASELS & 40 & AYGAZ \\
\hline 8 & BRISA & 41 & BIMAS \\
\hline 9 & CCOLA & 42 & BIZIM \\
\hline 10 & DOHOL & 43 & BRSAN \\
\hline 11 & FROTO & 44 & CRFSA \\
\hline 12 & KORDS & 45 & DEVA \\
\hline 13 & MGROS & 46 & EGEEN \\
\hline 14 & NETAS & 47 & ENKAI \\
\hline 15 & PGSUS & 48 & EREGL \\
\hline 16 & SKBNK & 49 & GOODY \\
\hline 17 & GARAN & 50 & GOLTS \\
\hline 18 & TAVHL & 51 & GUBRF \\
\hline 19 & TKFEN & 52 & HURGZ \\
\hline 20 & TOASO & 53 & NTHOL \\
\hline 21 & TCELL & 54 & IZMDC \\
\hline 22 & TMSN & 55 & KARSN \\
\hline 23 & TTKOM & 56 & KARTN \\
\hline 24 & HALKB & 57 & KONYA \\
\hline 25 & VAKBN & 58 & ODAS \\
\hline 26 & ULKER & 59 & PRKME \\
\hline 27 & VESTL & 60 & PETKM \\
\hline 28 & YKBNK & 61 & SELEC \\
\hline 29 & ZOREN & 62 & TATGD \\
\hline 30 & AKCNS & 63 & TUPRS \\
\hline 31 & DURDO & 64 & THYAO \\
\hline 32 & IHEVA & 65 & TTRAK \\
\hline 33 & PETUN & 66 & TBORG \\
\hline
\end{tabular}


Kalash, I. (2020), "Environmental Disclosure: Determinants and Effects on Financial Performance? An Empirical Evidence from Turkey", Sosyoekonomi, Vol. 28(46), 95-115. 